\title{
Truth and Procedural Fairness in Chinese Criminal Procedure
}

\section{Law}

\author{
Alexander Shytov \\ University of Chiang Mai, Chiang Mai, Thailand. \\ E-mail:shytov@yahoo.com \\ Peter Duff \\ University of Aberdeen, Aberdeen AB24 3UB, Scotland, UK; University of Chiang Mai, \\ Chiang Mai, Thailand. \\ E-mail:p.duff@abdn.ac.uk
}

\section{Introduction}

Chinese criminal procedure is a fascinating object of study. It is particularly dynamic at the moment and reflects changes in Chinese social, political, and economic life. Criminal procedure law is constantly evolving by trying to accommodate various conflicting social needs and demands. The speed of legislative change in China is such that many recent academic works have already become outdated to a greater or lesser extent. For instance, McConville and Pils (2013), contains a long 'Postcript' (pp. 455-503) commenting on the 2012 revision of the Chinese Criminal Procedural Law CPL), ${ }^{\mathrm{i}}$ which post-dated the contributions to this major volume on criminal justice in China. Therefore, our aim in this paper is not primarily to produce an up-to-date description of Chinese criminal procedure, an account that would soon become outdated because of more reform, but to attempt to understand the dynamic of legislative change. There is a need to concentrate not so much on the specific provisions of criminal procedure law as on the forces which shape and determine their content. This study looks at the ideological forces, or the fundamental ideas which shape the structure of Chinese criminal 
procedure law, although we will make some more practical, empirically based, observations where particularly relevant.

The most prominent idea in Chinese criminal procedural law is that it is focused on 'obtaining objective truth rather than satisfying rules of evidential discovery' (Yin \& Duff, 2010, p.1136; see also Zhang \& Yang, 2018). This search for the truth is the reason why the principle of double jeopardy, or ne bis in idem, is still not accommodated by Chinese law. Reflecting the emphasis on the search for the truth, until the reforms under the '2010 Evidence Rules' (Lewis, 2011, p 631; Lin, Gu \& Chen, 2017; Sun, 2018) there were in reality few rules on admissibility (Lewis, 2011, pp. 650-655; Guo, 2017). This was extremely significant because in China 'the confession is king' and to secure a confession was, and is, seen as vital in every criminal case (Belkin, 2013, p. 95; Guo, 2107). The undergoing reform of the law, however, attempts to reconcile the imperative of establishing truth with the idea of a fair trial (Long, 2015b). As we shall see, an important part of this was establishing the principle of admissibility as a practical reality. It is important to note that the Chinese concept of fair trial is different from its western counterpart. It goes beyond the concept of individual autonomy and affirms a variety of social and moral values. Chinese procedural criminal law attempts to present a greater unity between law and morals which aims to lead to an acceptance of the outcome of criminal proceedings by the public (and a greater efficiency).

Thus, the subject of this research is to examine the way in which Chinese criminal procedure attempts to reconcile the search for the truth with the ideal of fair trial or procedural fairness. At the outset, there are two basic questions are to be answered. First, is the pursuit of substantive truth in Chinese law achieved at the expense of procedural certainty? Second, does this pursuit make impossible the establishment of procedural safeguards for fairness and the 
rule of law? In tackling these two questions, considerable attention will be paid to the normative framework of Chinese criminal procedure because it is evident that, in practice, any system of criminal justice can be abused. Therefore, this research focuses not solely on the actual application of procedural rules but on analyzing the normative framework to perceive the way in which the imperative of finding the truth is related to the idea of procedural fairness.

\section{Truth v Fairness}

The amount of literature on Chinese criminal procedure law is substantial and, as noted above, much of it has become outdated because of the speed of legislative reform. The literature that deals with the foundational ideas of Chinese criminal procedure tends to focus on two basic issues. The first is the attempt to categorise Chinese law generally within a particular family of legal systems (David \& Brierley, 1985; Zweigert \& Kotz, 1998; Glenn, 2014) and, more particularly, within a particular model of criminal trial (see Yin \& Duff, 2010, for further references and discussion of this literature.) The second issue concerns the extent to which Chinese criminal procedure law reflects the principles of the rule of law and fair trial, along with the idea of human rights (McConville, 2013).

In relation to the first issue, there is a general consensus that China follows an inquisitorial model of criminal trial, meaning that the emphasis is on finding the truth rather than on the prosecution or defence winning the contest as in the adversarial model (Damaska, 1973). Nevertheless, some authors point to the influence of adversarial ideology since the reforms of 1996 (McConville, 2011, p. 10). However, this trend has also been noted in European inquisitorial jurisdictions, largely owing to the influence of the European Court of Human Rights, leading several comparative scholars to speculate that the adversarial and inquisitorial 
traditions are converging (Weigend, 2003; Jorg, Field \& Brandt, 1993; McConville, 2013, pp. 50-51). Nevertheless, significant ideological differences remain between these two models (Roberts, 2008). A number of commentators on Chinese criminal procedure have noted the difficulties of combining both the inquisitorial and adversarial traditions in the Chinese legal context (Capowski, 2011; Liu \& Halliday, 2009). Yu (2007, 69-70), for example, wrote that 'the absence of witnesses in the Chinese court contrasts with this reformed adversarial format.' In this context, it is interesting to note that in Europe, inquisitorial systems have been forced by decisions of the European Court of Human Rights to provide the defence with more opportunity to confront and question prosecution witnesses either at trial or as part of the formal pre-trial procedures. ${ }^{\text {ii }}$

For some Chinese scholars, the inconsistencies between inquisitorial and adversarial systems are of little practical significance. Professor Wei Pei from Beihang School of Law in Beijing, in correspondence with one of the authors of this article, expressed an attitude common among Chinese scholars as well as practitioners. In her view, there is no contradiction between the adversarial and inquisitorial elements of the revised Chinese law on criminal procedure. A Chinese judge does not per se have the obligation to verify the evidence presented at trial. If there is doubt about the evidence presented in court by the prosecutor or the defense, the judge has limited power to demand or collect additional evidence. In Chinese criminal procedure, the way to discover truth is not through confrontation with witnesses but through the cooperation of all official participants in the process. Indeed, this view is very clearly articulated in Article 7 of the CPL: 'In conducting criminal proceedings, the People's Courts, the People's Procuratorates and the public security organs shall divide responsibilities, coordinate their efforts and check each other to ensure the correct and effective enforcement of law.' 
We would observe that, in the eyes of most comparative scholars, the Chinese judge's limited involvement in the verification of evidence would be a hallmark of adversarial procedure while the emphasis on cooperation in this regard closely resembles that of inquisitorial ideology (Damaska, 1973; 1986). Therefore, according to Professor Wei Pei, both traditions seem to be comfortably accommodated within Chinese criminal procedure. In our view, however, there still exists an underlying tension: if the trial judge is not satisfied that the cooperative efforts of the parties have produced all the evidence that is, or might be, available, what should he do? Is his essential stance passive, as in the adversarial model, or active, as in the inquisitorial model? Further, how does the defence fit into this schema? In an adversarial model, the role of the defence in gathering and submitting evidence at trial is critical, yet under Article 7 above, the defence is not even mentioned (see Zuo \& Ma, 2013; Nesossi, 2013).

In any event, it is difficult to identify Chinese criminal procedure law with a particular legal family. David and Brierley (1985, pp. 20-21) suggest that ideology, as embracing philosophical, political, and economic principles, is one of the two main criteria for differentiating legal families. Another possible criteria is the hierarchy of legal sources, institutions and methods. It is a mistake to think of procedural law as ideologically irrelevant because "criminal procedure, as "applied constitutional law", is normally one of the most useful branches of law in terms of identifying the ideology of a regime' (Yin \& Duff, 2010, p. 1111; see also McConville, 2013). In this context, it is significant that in the United States, criminal procedure is perceived to be an aspect of constitutional law with all the political and ideological baggage which that entails (Whitebread \& Slobogin, 2003: ch. 1). Similarly, Chinese criminal procedure law possesses constitutional significance. The Chinese constitution itself mentions some basic principles of criminal procedure, for example, the right to counsel and the public nature of the trial (Article 125) as well as judicial independence (Article 126). But those 
provisions remain very brief and undeveloped. Therefore, the criminal procedure law itself has become the main source of constitutional significance. Professor Ji Weidong calls it 'our little constitution' (Balme, 2012, p. 6) and refers to the enormous public attention that the undergoing reform of criminal procedure law has received in China.

Some scholars describe the modern stage of the development of Chinese law as 'breaking off the shackles of ideological domination' or 'the abandonment of ideology' (Chen, 2008, p. 75) but Chinese criminal procedure still contains a strong ideological element. Article 1 of the CPL claims that 'maintaining socialist public order' is one of its purposes. Article 6 of the same law requires that 'in conducting criminal proceedings, the People's Courts, the People's Procuratorates and the public security organs must rely on the masses.' Nevertheless, it is evident that the presence of Marxist or Maoist statements in Chinese criminal law legislation has been gradually reduced (Keith \& Lin, 2001, p. 207). The ideological shift from class struggle to the maintenance of law and order is apparent to many commentators (Chen, 2013, p. 62). The ideological content of criminal procedure can be seen not merely in the general political statements from the legislation quoted above, but also in the political and moral values protected or neglected in its provisions. Some writers, for example, note a weak expression of the idea of individual legal autonomy in the procedural structure itself. As Yin and Duff put it: the purpose of Chinese procedural law 'is not to resolve conflicts amongst individuals but to achieve a collectivist society and socialist morality' (2010, p. 1106). The dominant position of the Communist Party and political doctrine in criminal law and procedure is also identifiable and striking (McConville, 2013).

It is apparent to most commentators that Chinese criminal procedure has abandoned the Soviet law model in which 'the administration of justice was rendered mainly by the security agencies 
and special tribunals' (Yin \& Duff, 2010, p. 1112). Even though China has now adopted many elements of the civil law tradition, the predominance of public law and the public good, rather than private interests, persists (McConville, 2013). This predominance has a long historical tradition in China. Confucianism contains an anti-capitalist and to some degree, a socialist sentiment, although it is not democratic by any means (Guo, 2003, p. 5). After the Maoist reaction against Confucianism (De Bary, 1998), the latter is experiencing a revival, to a limited extent, in modern Chinese intellectual culture (Bell, 2008, p. 22). It is very difficult to isolate the Confucian element in the Chinese socialist system, as Confucianism has never been an influence which can be disentangled and viewed in isolation from the rest of Chinese culture. From the beginning, it was intermingled with the Chinese philosophical tradition of Legalism which also persists in modern China (Chen, 2008, p. 20). Thus, Chinese law can be generally classified within the socialist law family (Yin \& Duff, 2010), but also including the Confucian and Legalist philosophical traditions. One apparent influence of Confucianism can be seen in the idea that criminal procedural law has an educational function. Article 2 of the CPL, for example, states that its aim is 'to enhance the citizens' awareness of the need to abide by law and to fight vigorously against criminal acts.'

Against this backdrop, many authors suggest that Chinese criminal procedure law lacks the idea of a fair trial, sometimes explaining this by its adherence to inquisitorial ideology (Simon, Feng \& Nelson, 2016, p. 4; see also Nesossi, Biddulph, Sapio \& Trevaskes 2016) and sometimes by the specifically Chinese structural and cultural contexts of the court's proceedings (Lu \& Miethe, 2007, p. 21; Chen, 2008, p. 324). The assessment of fairness of Chinese criminal procedure is often influenced by the political views of commentators. Proponents of a liberal democracy may deny that the principle of fairness plays a significant role in the criminal justice process in modern China (Peerenboom, 2002, p. 14), a typical 
conclusion being that ' $(\mathrm{t})$ he prevailing conception of class struggle rooted in the Chinese communist State has caused enduring inconsistency between Chinese criminal procedure and western notions of the rule of law' (Yin \& Duff, 2010, p. 1113).

Not all authors, however, apply western notions to describe the Chinese position. Some claim that the idea of a fair trial is not new to China by tracing it back to the Qing Dynasty, if not earlier (Zhang, 2014, p. 390). It is acknowledged that Communist China at its outset operated with a very different set of ideas from those of the rule of law, fair trial, and human rights (Fang \& Li, 2017, p. 10). However, since 1978, there have been clear signs that Chinese law and policy makers are trying to ensure that the principle of fairness (in the Chinese understanding) is realized (Blasek, 2015, p. 64). In more practical terms, this new policy has led to the abolition of the police power to order re-education through the labour system in 2013 (Xinhua, 2013) which was widely considered as inconsistent with the idea of rule of law and fair trial (Zou, 2006, p. 186). In the next section, we will try to demonstrate how the concept of a fair trial is now reflected in the texts of Chinese criminal procedure legislation. ${ }^{\text {iii }}$

\section{The Exclusionary Rule}

If evidence testifies to the truth, but it was obtained by inappropriate or illegal means, such as torture, should or should not judges take it into account in reaching their verdict? The answer to this question reveals a lot about the relationship between truth and procedural fairness in any individual criminal procedure system and that state's ideological stance om balancing individual autonomy and civil liberties against society's need to deal with crime and maintain public order. Therefore, it is extremely significant, particularly in view of the central role of the confession in China, that in 2010 a structured regime to exclude forced confessions was introduced to Chinese criminal procedure 'with great fanfare' (Belkin, 2013, p. 102) This was 
achieved through the 2010 Evidence Rules, which were jointly issued by five government bodies and covered separate sets of rules relating to (1) evidence in death penalty cases and (2) the exclusion of illegally obtained evidence.$^{\text {iv }}$ Lewis, (2011) provides a detailed account and analysis of the history of these reforms and the reasons behind them (see also Belkin (2013, pp 98-105). In this context, it is the exclusionary rule which is of interest, and this important new element in Chinese criminal procedure was reinforced by the 2012 reforms to the CPL. Article 54 states:

Confessions extorted from a criminal suspect or defendant by illegal means such as torture, testimony of witnesses and statements of victims collected by violent means, threat or other unlawful means shall be excluded. Physical evidence or documentary evidence that is not collected according to statutory procedures and is therefore likely to materially damage judicial justice shall be subject to correction or reasonable explanations and shall be excluded if correction or reasonable explanations are not made. Evidence that shall be excluded as found during investigation, examination before prosecution and trial shall be excluded in accordance with the law and shall not serve as the basis for making prosecution opinions, prosecution decisions and judgments.

Even though this article has been criticized for making a distinction between evidence which must be excluded and the evidence which may be excluded (Sun, 2017, p. 167) (a distinction common in many jurisdictions (Duff, 2004: Roberts and Zuckerman, 2010, ch. 5), it is still an important procedural safeguard of fairness.

There are at least three significant problems hindering successful application of the exclusionary rule in the Chinese context. The first problem is that the general idea of the 
unacceptability of torture and violence in obtaining evidence may be interpreted differently because the concept of torture and violence depends on certain moral standards affirmed by an individual conscience or moral sense which differs from person to person. For example, interrogating a suspect for many hours late at night did not appear morally wrong to Soviet prosecutors (Solzhenitsyn, 2003) nor was 'water-boarding' deemed to be torture by the USA during the Bush presidency (Goldberg, 2007 p. 213). Guo (2017, pp 34-37) explains in detail the difficulties that the actors in the Chinese criminal justice system have faced in interpreting what constitutes torture of illegal means under Article 54. Further, in China, torture of an innocent is evil, but 'torture of someone who ultimately appears to be guilty, however, seems to be something many are prepared to overlook' (Daum, 2017).

Second, the suppression of a confession will usually result in the prosecution simply obtaining a new and 'flawless' confession from the accused (Guo, 2017, p. 48). Daum (2017) describes some cases, when police or prosecutors, knowing that that a confession might be excluded, have simply carried out a new and lawful interrogation to get an admissible confession. Further, as Guo (2017, p. 39-40) explains, the accused will usually have made several confessions during the investigation process, both to the police and the Procuratorate, and if one is rendered inadmissible, then there is no consensus as to whether any subsequent confessions are thereby tainted and should be excluded by the court. Finally, there is no 'fruit of the poisoned tree' doctrine in Chinese evidentiary law and a new confession, to replace one that is inadmissible, or physical evidence obtained as a result of an inadmissible confession remain admissible (Gelkin. 2013, p. 107: Guo 39-40; Daum, 2017, pp.4-5).

The third problem lies in the way law is perceived in China, as well as in many other countries, where criminal procedure is perceived as a command, rather than a set of principles for 
adjudication. The inadmissibility of evidence obtained through torture, violence, or threat, does not fit comfortably with the image of law as a set of detailed instructions underpinned by the threat of punishment. It is somewhat vague, particularly in terms of its application. As Guo (2017, p. 40) observes, not having a 'case law tradition' to rely on, police, prosecutors and judges feel 'helpless' when trying to operationalize the principles underlying the admissibility test when a practice is not 'expressly forbidden'. Therefore, for many Chinese critics of the new law, it was not enough merely to express the principle of inadmissibility in statutory form in a country where people are more accustomed to obeying specific commands backed up by very specific sanctions (Sun, 2018).

There was an attempt to address this problem by issuing more detailed rules on exclusion of illegal evidence. In June 2017, they were jointly issued by the Supreme People's Court, the Supreme People's Procuratorate, and the Ministry of Public Security (Yi, 2017). The rules are contained in regulations entitled Notice of the Supreme People's Court, the Supreme People's Procuratorate, the Ministry of Public Security and Other Departments on Issuing the Provisions on the Several Issues concerning the Strict Exclusion of the Illegally Collected Evidence in the Handling of Criminal Cases. ${ }^{\mathrm{v}}$ It is worth noting that the length of the name of this document is not unusual in China and reflects the ideology of cooperation between all state organs in legal regulations. The problem of the rules on admissibility being too general still persists however, because most of the above document's provisions remain rather broad. Nevertheless, the rules do attempt to spell out in more detail the mechanisms for excluding illegal evidence. First of all, they emphasize the right of the accused to challenge the legality of the evidence before the procuratorate at the time of the investigation, in other words before the trial process begins (Article 14), and impose a duty on the investigating organ and the procuratorate to ensure that there was no incident of torture or a forced confession (Articles 15, 
17). In order to strengthen the protection now offered to an accused, the new rules also require that at the commencement of the criminal court's proceedings, the court must inform the accused of his right to apply for the exclusion of illegal evidence (Article 23). According to Article 33 of the same Rules, evidence that is disputed because the accused claims that he was mistreated during interrogation cannot be read or referred to in cross-examination before the court makes a decision on whether to exclude it or not. Nevertheless, it is clearly stated that if there is no proof that the evidence was obtained illegally, the court will refuse to exclude it (Article 24).

Whereas these provisions do not require the accused to prove the facts of torture, violence or mistreatment etc., there is a great deal of confusion over the relevant evidential burdens (Lewis, 2011, p. 665; Guo, 2017, pp. 41-45). It is accepted that the defence must provide some evidence in order to persuade the court to address the question as to whether a confession should be rendered inadmissible on the grounds of the accused's ill treatment. Even this level of information can be difficult for the accused to secure, not least because there is uncertainty over the standard of proof, however minimal, which is required. If this weak evidential burden is met, in theory the prosecution must prove beyond reasonable doubt that the confession was lawfully obtained. To this end, the following methods of proof are envisaged under the 2010 exclusionary law: the provision of the interview transcripts, or audio or video recordings of the interrogation (the latter being compulsory in the most serious of cases); an interrogator testifying in court; or the provision of an official written explanation of the circumstances of the interview. It should also be noted that a physical examination of the arrested person is required to ensure that he did not suffer any physical violence or torture at the hands of the police or other state organs (Article 13 of the CPL). However, it would be somewhat naïve to believe that interrogating officers who have employed such methods are always likely to have 
recorded the interrogation, and/or retained it, or will admit to anything unlawful in court or have left any physical signs of the mistreatment of the accused. It is worth observing that the only practical solution to the difficulty the accused faces in obtaining proof of torture, violence or its threat would be to require the police to prove that the interrogation was legitimate by producing the audio-video recording of it. If they do not do so, then any disputed confession given by the accused could be deemed inadmissible as evidence against the accused.

In any event, at the moment, if the accused offers some proof of the illegality of his interrogation by the police, then the court should convene a pretrial conference to determine the issue (Article 25). Additionally, Article 182 of the CPL, among other things, now states:

before the commencement of a court session, judges may convene a meeting with the public prosecutor, the party concerned and his/her defender and agent ad litem to deliberate and consult their opinions on withdrawal, the list of witnesses, exclusion of illegal evidence and other trial-relevant issues.

A pretrial conference system is a new feature of Chinese criminal procedure law but it is worth observing that it is a mechanism which is common elsewhere. For example, pre-trial hearings aimed at settling all evidential issues before the trial starts have been held in Scotland and England, both of which are adversarial systems, for over twenty years (Renton and Brown, 2018, chs. 17 \&20; Blackstone's Criminal Practice, 2008, D4, 5 \& 15). Further, the Chinese model also resembles to some extent Article 17 of the United States Federal Rules of Criminal Procedure (see US House of Representatives, 2016). Guo (2017: pp. 48-49) notes that in practice pre-trial conferences have not worked well in China in terms of excluding 
illegitimately obtained confessions but, in our view, they could be turned into a more effective, if far from perfect, mechanism as they are in the jurisdictions mentioned above.

Article 26 of the 2017 Rules states that if the public prosecutor and the defendant do not reach agreement on whether the collection of evidence has been legal in the pre-trial conference, and the people's court has doubts about the legality of the collection of evidence, the court shall conduct an investigation during the trial. ${ }^{\mathrm{vi}}$ According to Article 34, if the court has doubts about the legitimacy of the collection of evidence based on relevant testimony or materials, and the People's Procuratorate fails to provide proof of its provenance or the proof provided cannot confirm the legitimacy of the evidence, and it cannot be ruled out that it was collected illegally, then the evidence should be excluded. However, Lewis points out that, traditionally, judges have been reluctant to 'break with the police and prosecutors' $(2011, \mathrm{p} .683)$, and that senior Chinese academics express 'skepticism' the judiciary will have the 'courage, ability and motivation' to exclude evidence (2011, p. 689-690). It should be noted the decision of the court on exclusion of evidence can be appealed to the higher court (Article 40). It is evident that the effectiveness of the application of the exclusionary rule depends in the end on the capacity of a Chinese judge to doubt! But what if the judge is not trained to doubt or does not want to doubt?

\section{The Judge and Truth}

However, the practicalities of the Chinese trial system save Chinese judges to a great extent from the painful experience of doubt because, as in most modern systems of criminal justice, the majority of defendants plead guilty (McConville, 2012: Dobinson, 2013; Guo 2017, pp. 1$2,30-51$ ), whether by right as in adversarial systems or in a disguised fashion as in inquisitorial 
systems (see Weigend, 2008). Accordingly, Article 227 of the Interpretation of the Supreme People's Court on the Application of the Criminal Procedure Law of the People's Republic of China, 2012 states:

In a case where the defendant has pleaded guilty to charges, after confirming that the defendant understood the facts and charges alleged in the indictment, voluntarily pleaded guilty and knew the legal consequences of the guilty plea, the court's investigation may mainly focus on sentencing and other controversial issues. In cases where the defendant does not plead guilty or the advocate maintains his innocence, the court investigation shall ascertain the facts related to sentencing on the basis of the facts establishing the guilt. ${ }^{\text {vii }}$

Since a defendant rarely claims innocence, and there are not many controversial issues left, Chinese trials are notorious for their speed, normally taking only few minutes (Sun, 2018). In this context, it would require a significant effort by judges to attempt to examine whether confessions are truly voluntary and the extent to which they are credible and/or reliable. The CPL contains some conflicting principles in terms of the role of judges in questioning the genuineness of evidence in general and of confessions in particular. On the one hand, Article 49 seems to suggest an adversarial model: 'The burden of proof of guilt of the defendant in a public prosecution case shall fall on the people's procuratorate, while that in a private prosecution case shall fall on the private prosecutor.' If such is the case, then judges should be normally be satisfied with what procurator presents in court providing that there are no objections to this evidence by the accused or a defence lawyer. In other words, they would not enquire into the method by which a confession was obtained. 
On the other hand, Article 50 of the CPL perhaps implies a rather different and more active role for the judge: 'Judges, prosecutors, and criminal investigators must, under legal procedures, gather various kinds of evidence that can prove the guilt or innocence of a criminal suspect or defendant and the gravity of crime.' Article 191 also envisages a more involved role for judges and spells this out in the following way: 'During a court hearing, if the collegial panel has doubts about the evidence, it may announce an adjournment, in order to carry out investigation to verify the evidence.' It then sets out various powers the People's Court has been granted for this purpose, for example, allowing the court to seek an expert evaluation of scientific evidence. Further, Article 220 of Interpretation of the Supreme People's Court on the Application of the Criminal Procedure Law of the People's Republic of China, 2012 similarly indicates that if the judge has any doubts about the evidence, active steps should be taken to resolve these:

If the court has any doubt about the evidence, it may inform the public prosecutor, the parties and their legal representatives, the advocate, and agents ad litem to supplement the evidence or make explanations. If necessary, the court may announce an adjournment to investigate and verify the evidence.' In other words, it is not a duty but it is within the discretion of the court to request additional information where it has doubts about the reliability of the evidence or presumably the method by which it was obtained.

Once again, one can see that judicial doubt is paramount in dictating the extent to which Chinese judges are prepared to carry out their own investigation into the quality of the evidence and the method by which it was obtained. Informal interviews with Chinese academics, conducted by one of the authors, indicate that even if the Chinese judges do have doubts, this is rarely expressed in the use of their own initiative to investigate further, confirming the view of Lewis which was described above. Further, in view of the centrality of confessions in China, 
McConville in a major empirical study found that judges very rarely challenged evidence from confessions (2012, p. 75). Be that as it may, Article 66 of the 2012 Interpretation imposes a duty on the court to inform the parties of the discovery of any important, new evidence: 'when the people's court investigates and verifies the evidence and finds new evidence material that has a significant impact on the conviction and sentencing, it shall inform the procurator, the advocate, the private prosecutor and his legal representative.' While this provision clearly covers what is often termed 'fresh' evidence, in the sense that it was hitherto completely unknown to any of the parties, it could, presumably also include evidence discovered by the judge that, for example, the police used illegitimate means to secure a confession from the accused during his interrogation. However, there is no duty laid upon the court to inform a defendant or a defence lawyer, again indicative of the mindset that the prosecution is a team effort by the state agencies, rather than an adversarial contest.

One can see that the Chinese courts have enormous discretion to collect additional evidence. They also have the power to accept or reject submission of new evidence by the parties. The discretion to reject a submission, however, is burdened by a duty to provide reasons for the rejection:

If during the trial before the court, the parties, their advocates, or agents ad litem request to notify the new witness to appear in court, to obtain new evidence, or apply for reassessment or inspection, then the name of the witness, the location of the evidence, the explanation in relation to the facts of the case, and the reasons for a new inquest or expert examination shall be provided. If the court deems it necessary to agree, it shall announce an adjournment of hearing; if it disagrees, it shall explain the reasons and continue the 
trial (Supreme People's Court, Interpretation of the on the Application of the Criminal

Procedure Law of the People's Republic of China, 2012, Article 222).

The interpretation, however, does not specify the manner and the form in which this explanation must be given.

It is obvious that, theoretically, the resolution of judicial doubt can be achieved only through an examination of all relevant materials collected by the procuratorate. It is unlikely, however, that without assistance, the court will be able to identify any relevant evidence that is not included in the file submitted to the court by the prosecution. In this regard, the role of a prosecutor and a defence lawyer is paramount in ensuring disclosure to the court of all relevant information in the hands of the police or in the prosecutor's file.

\section{The Prosecutor and Truth}

While it is possible for a private person to initiate criminal proceedings, it is the procuratorate which has the sole power to initiate public prosecution (Article 3 of CPL). The Chinese procuratorate takes a unique position in Chinese criminal procedure, since it is not only the public prosecutor but also the public guardian of lawfulness, the authority to approve arrests and the organ empowered to conduct investigations (Article 3 of CPL). In ordinary cases, the investigation is carried out by the police but in serious cases, including the extortion of a confession by torture, the procuratorate alone performs the function of investigation (Article 18 of CPL). There are reports, however, that from the end of 2016, the procuratorate has being undergoing substantial reform, and that its investigative function is largely being abolished, with more emphasis being placed on its main function of legal supervision (Long, 2018, 147). There is much confusion at the moment about the future function of the procuratorate which 
illustrates well the fact that the recent transformation of the Chinese criminal procedural law has brought about a degree of uncertainty to the law.

Chinese academics speak about three confusions (三乱) when discussing the current reforms of the procuratorate system. This condition was described by Zhang (2011) several years ago, and it is said to have been aggravated as the reforms proceeds (Long, 2018, 141) owing to the fact that procuratorates on all levels adopt different policies and practices in implementing the reforms. Zhang singled out confusion in the institutional setting (机构设置乱), confusion in institutional designation (机构名称乱), and confusion in the mechanism for delegating authority (派出机构). The increase of uncertainty as the reform proceeds might well illustrate well the philosophical dictum of Laozi against preoccupation with continuous intervention: "leaving muddy waters undisturbed will make it actually clear." viii The prudent advice of Laozi seems to be largely ignored in contemporary China, as most Chinese academics and practitioners, including Zhang and Long argue for more regulations in the hope that new laws make the entire criminal justice process clear and smooth. This hope is likely be in vain considering the need for a greater shift in the fundamentals of Chinese criminal procedure than so far proposed.

There is, certainly, something to be done about the confused role of the procuratorate. Guo (2017, pp. 46-7) explains that the Chinese procuratorate:

is not a partisan prosecuting party as in adversarial systems. In contrast, it is not only a judicial organ but also a legal supervisory organ. Thus Chinese prosecutors have the authority as well as the obligation to exclude illegally obtained evidence to ensure the proper administration of criminal justice. However, wearing multiple hats, prosecutors 
find it difficult to remain as neutral as they should be. In most cases, prosecutors fail to exclude illegally obtained evidence out of a desire to pursue the prosecution.

He suggests that this unavoidable conflict of roles be solved by separating procuratorates according to their tasks: one section can deal with prosecutions, another with determining admissibility issues.

The views of Guo have been reflected by a number of leading Chinese academics, such as Chen (2011, p. 236) who claimed that 'the procuratorate cannot possibly have too great a role in excluding illegal evidence: it plays a greater role representing police and other official investigators in criminal litigation, and stands in an adversarial relationship to the defendant applying to exclude evidence'. This rather belies any idea that the procuratorate has a neutral obligation to exclude suspect confessions. The attempts to bring clarity into the operation of its diverse functions create a tension within the procuratorate, which on the one hand is based on a strict hierarchical principle and which at the same time has used its discretionary powers to develop extremely diverse practices at the grass roots levels (Long, 2018, p. 141). Any attempt to introduce more controls on the way in which evidence is collected will almost certainly be resisted on the grounds that it would affect the smoothness and speed of criminal proceedings. In many places, the procuratorate functions more as 'a bridge between the police investigation and court procedures than as a discriminating screen' (Lewis, 2011, pp. 652-653). There is also an uneasiness among the Chinese about the growing number of prosecutors (Lixin, 2009, p. 327).

The wheel of Chinese government reform turns fast and may turn in various directions. It is certainly appropriate that the procurator, who has to decide whether to initiate public 
prosecution, must retain the power to examine the legality of evidence. The procurator stands nearer to the process of collecting evidence and is certainly better positioned than a judge to decide on the admissibility and reliability of evidence which he has to present to the court. During the process of approving arrest and the decision to prosecute, the 2017 Rules oblige the procurator in charge to inform the accused of his right to apply for the exclusion of illegal evidence (Article 16). The consequences of discovering that the evidence has been obtained illegally is that the procurator is barred from sanctioning detentions and initiating prosecution, unless there is other supporting evidence (Article 18).

The role and power of the procurator reveals clearly the nature of Chinese riminal justice. It is certainly not adversarial. Is this system well suited for discovering the truth? Or does the partiality of the procurator as a prosecutor compromise the truthfulness of evidence submitted to the court? The 2012 reform of the CPL and 2017 Rules may provide sufficient normative grounds for a procurator to evaluate the legality of evidence submitted by the police. The doubt is whether he or she will be willing to ignore facts that may point to the illegality of such evidence. It is certain that much depends on the willingness of the interrogated person to report the facts of abuse, and also the willingness of the procurators to take such reports seriously. The 2017 Rules (Article 14) authorize the procurator to control the process of investigation in relation to illegal evidence not only at the request of the interrogated but also on his own initiative in more serious cases. Yu (2017, p. 631) in his empirical study in an unidentified location of China on how prosecutors and investigation officers work together on the issue of admissibility of evidence concludes: 'As long as the written evidence appears lawful in format and conforms to legal requirements, the police case is approved by prosecutors, disregarding the methods of construction.' However, Guo (2017, pp. 46-47) refers in his empirical study to various cases where prosecutors were active in uncovering the illegality of evidence and 
concluding that it is inadmissible. They do this when authorizing detention and more so when deciding on whether to initiate prosecution or not. As noted above, Guo suggests creating a separate section in the procuratorate to rule on the admissibility of evidence, separate from those responsible for prosecution, in order to avoid any conflict of interest (2017, pp 46-47). In the cases he mentions, however, it seems that what persuades Chinese prosecutors to reject coerced confession is an awareness of the problem and a political will to stop malpractice in line with the current reform of criminal procedure in China.

How long this political will lasts is open to question. Creating an additional controlling mechanism suggested by Guo could certainly prolong this current campaign, but it is unlikely to inspire further efforts. As with 2017 Rules, procedural mechanisms alone are not sufficient to enable procurators to exercise efficient control over the process of investigation. What is essential is the moral authority and respect they engender in the eyes of the other players in the system and the public, which will enable them to stand up to the police and create trust among accused to report the facts of procedural abuse.

\section{The Defence Lawyer and Truth}

In practice, if a defence lawyer, representing the accused, does not object to evidence, which is the normal defence response, a judge has very little ground for doubting the truthfulness or the provenance of the evidentiary materials submitted to him by the prosecution. Dobinson (2103) explains that a defence lawyer will usually see little point in challenging the event because this will very rarely have a positive result in terms of the verdict and is likely to increase the sentence imposed on his client. Further, such actions will open up the lawyer to 
harassment and possibly even arrest by the authorities (see also Rongjie, 2013). At this point, it is worth noting that in the inquisitorial model, the defence lawyer traditionally has tended towards a passive role as regards the investigation and questioning of witnesses (Field \& West, 2003; Hodgson, 2005, ch. 4). As we saw above, in theory, it is possible for judges, on their own initiative, to ask for further information or seek it themselves. Further, Article 226 of Interpretation of the Supreme People's Court on the Application of the Criminal Procedure Law of the People's Republic of China, 2012 states:

During the trial, if the collegial panel discovers that the defendant has surrendered on his own initiative, confessed, or performed a meritorious service, that according to law is a mitigating circumstance, and if there is no relevant evidential materials in the file submitted by the People's Procuratorate, it shall notify the People's Procuratorate to submit it.

It is apparent, however, that such information is more likely to be discovered and disclosed with the active involvement of a defence lawyer, rather than relying on the prosecutor to bring it to the attention of the court or the court making the relevant enquiries itself.

At this stage, it should be noted that according to Article 42 of the CPL:

No defense lawyer or any other person may help a criminal suspect or defendant conceal, destroy or fabricate evidence or collude with a criminal suspect or defendant to make confessions tally, or intimidate or induce witnesses to give false testimony or conduct other acts interfering with the proceedings of judicial organs. Any violation of the preceding paragraph shall be subject to the legal liability in accordance with the law. Any 
alleged crime committed by a defender in this regard shall be handled by an investigating organ other than the investigating organ handling the case undertaken by the defender.

While this imposes similar duties as an 'officer of the court' on the defence lawyer as elsewhere (Ashworth and Redmayne, 2010, pp. 65, 73), at the same time, the 2012 reform has given defense lawyers more rights to gain access to evidence. Article 39 of the CPL states that if the defence thinks that a public security organ or the procuratorate has failed to submit evidence gathered during the pre-trial proceedings which 'can prove that the criminal suspect or defendant is innocent or the crime involved is a petty offense', the defence is entitled to apply to the procuratorate or the court to obtain such evidence. In other words, finding the truth will depend sometimes not only on the truthfulness and completeness of the evidence submitted by the prosecution, but also upon the preparedness and persistence of defense lawyers in obtaining all the relevant evidence. As noted above, however, there are strong incentives for a defence lawyer to remain inactive.

The powers of the defense lawyers to apply for disclosure of evidence held by the procuratorate is limited, as it is elsewhere, to material which is relevant (Ashworth and Redmayne, 2010, pp. 238-248). It important to note, however, that, as is the norm in inquisitorial systems, the defence has access to the case file which has been passed from the police to the procuratorate. As regards any evidence which is not in the case file, the defence can seek disclosure, or discovery (in the American terminology), only if that evidence might show that the criminal suspect or defendant is innocent or there is a mitigating circumstance (Article 224 of the Interpretation of the Supreme People's Court on the Application of the Criminal Procedure Law of the People's Republic of China, 2012). In this situation, the Chinese court, after receiving an application from the defence lawyer, can order the procuratorate to hand over any 
evidentiary materials collected during the investigation, examination and prosecution, and it must do so within three days after receiving the letter from the court allowing the defence to obtain the evidence. Thus, it is not all the evidence in the prosecution file which the defence lawyer has the right to access but only that which can be demonstrated to the court as being important for proving the defendant's innocence or the presence of a mitigating circumstance. In practice, however, Daum (2017, pp, 5-6) claims that defence lawyers have had little success in securing records of medical inspections carried out upon their clients at detention centres in order to prove allegations of confessions being coerced.

\section{Witnesses and Truth}

The theoretical capacity of defence lawyers to challenge the background to and truthfulness of evidence submitted by the prosecution depends much on their access to witnesses and to the records of the latter's earlier statements and testimony at trial. Much of this information remains out of the knowledge or control of the defence lawyer. A witness could have been subject to torture, violence, threats, etc. If so, it is vital that there is an opportunity for the defence to cross-examine witnesses. The fundamental problem faced by the Chinese criminal justice process is that witnesses are rarely examined in oral proceedings before the court (Wang and Caruso, 2017). As Lewis (2011, p. 665) observes, focusing 'attention on in-court-testimony goes against deeply embedded practices in the criminal justice system'. For this reason, Belkin (2013, p. 104) explains that the new requirement for interrogators (usually the police) to testify in court where there are doubts over the admissibility of a confession is 'unprecedented' and, in the eyes of the police, demeaning to them (see also Lewis, 2011, pp. 665-666). Consequently, interrogators are rarely summoned to court to answer questions about the possible abuse of suspects who have confessed (Daum, 2017, pp. 6-7) 
Tradition aside, there are several reasons why civilian witnesses in particular are rarely examined in open court proceedings, a significant factor being the unwillingness or fear of the witnesses themselves. To address this problem, Article 62 of the CPL put in place a number of measures to protect witnesses, including securing their anonymity. It is difficult, however, for the Chinese criminal justice system to create an atmosphere in which witnesses will willingly come forward and testify to the truth rather than having to be compelled to come to court, feeling anxious if not scared. Thus, obtaining the truth in any particular case will depend to a great extent on the attitude of witnesses to court proceedings.

Since witnesses rarely attend trial proceedings, it would be natural to expect that defence lawyers should have an opportunity to meet them before the trial to evaluate them and their testimony. In various inquisitorial jurisdictions, for example, the Netherlands, witnesses traditionally were usually not called to give evidence at the trial (see Swart, 1993, p. 298) but the ECHR jurisprudence has disapproved of this practice and, nowadays, while there are various exceptions to the rule that witnesses must be available at trial for cross-examination, in such circumstances the defence must have the opportunity to question witnesses during the pretrial proceedings (Trechsel, 2005, pp. 305-322). The Chinese position is less clear. Article 41 of the CPL states the following:

Defence lawyers may, with the consent of the witnesses or other units and individuals concerned, collect information pertaining to the current case from them and they may also apply to the People's Procuratorate or the People's Court for the collection and obtaining of evidence, or request the People's Court to inform the witnesses to appear in court and give testimony. With permission of the People's Procuratorate or the People's 
Court and with the consent of the victim, his close relatives or the witnesses provided by the victim, defence lawyers may collect information pertaining to the current case from them.

It should therefore be noted that defence access to witnesses and the latter's appearance to answer questions at trial depends either upon witnesses being willing to cooperate before the trial or the court agreeing to them being compelled to appear at trial.

Against this backdrop, it is not surprising that the modern state of Chinese criminal procedure law is unsatisfactory from the point of view of the defence. Quite simply, courtroom culture and broader social attitudes do not perceive it to be the norm that the accused will dispute his or her guilt nor that witnesses will give evidence at trial as a matter of course. In other words, the key problem to be resolved as regards the Chinese criminal trial is to make it commonplace for all testimony to be heard before the judge in open court and for witnesses to accept that this is the usual procedure. Despite significant efforts to make this possible, the new normative framework still remains powerless to give life to a trial that is centered on obtaining the truth without any element of compulsion being involved. Culture and tradition need to change in order to create a meaningful trial.

\section{Conclusion}

The reform of criminal procedure in China did not stop with the issue of the '2010 Evidence Rules' and the revisions to the CPL in 2012. By October 2014, the 18th Central Committee of the Communist Party had announced a new policy to reform the Chinese court system generally and criminal justice particularly. ${ }^{\text {ix }}$ There is an awareness that the trial proceedings remain a formality, whereby the court simply approves or 'rubber-stamps' the findings presented to it 
by the procuratorate. Therefore, in February 2015, the Supreme Court of the PRC published guidelines for the reform of court proceedings according to which the examination of the facts (including cross-examination) must become the central part of the trial. (Sun, 2018). Unfortunately, modern Chinese scholarship tends to focus on how to perfect procedural mechanisms to achieve this rather than on how to change the fundamental intellectual and moral attitude to the idea of trial among ordinary people. As a leading Chinese academic, Chen (2010, p. 529), wrote: 'Any perfect modem system and management expertise and any cuttingedge technologies would turn into a pile of waste paper in the hands of a bunch of traditional minded people' (see also Long, 2015). In similar vein are Lewis' comments on the introduction of the exclusionary rules: 'This move will require that assertive actors in the criminal justice system gain a toehold and gradually move the rule from the realm of gloss to substance.' (2011, p. 636).

The same conclusion can be applied to the belief of Chen (2010, p. 518) and Zuo (2015), as well as other prominent Chinese academic scholars, that the only way to procedural fairness is an increase of the adversarial elements in Chinese criminal procedure. Adversarial mechanisms are unlikely to work in a society where the defence, on one side, is not - and presently cannot - be perceived as an equal party to the police and prosecution, on the other side, even if the Chinese judge poses himself as an independent arbiter. To change this system might require a cardinal departure away from a single-party authoritarian state towards a pluralistic society with independent courts and even independent procuratorate.

In brief, an open trial with active participation of witnesses and the defence will remain an unachievable goal without a fundamental shift in the way how the 'truth' is obtained. At the moment, the primary method of finding the truth is the inquisitorial work of investigators, in 
securing a confession, the procuratorate, in confirming the acccused's confession, and to a lesser degree, the judges in validating it. It is difficult to reconcile this with the concept of procedural fairness which the Chinese written law now tries to reflect. The search for truth and procedural fairness can be reconciled only if truth is obtained through an active and open interaction of the prosecution, the defence and/or accused, the victim and other witnesses in a public forum. This interaction does not need to be antagonistic and confrontational in the same manner as it is perceived in the West where adversarial trial carries a sense of mutual hostility. Chinese culture and values, as described briefly above, could contribute to a more cooperative and less partisan context for seeking the truth. Whatever form the adversarial aspects of criminal procedure take in China, its future depends not so much on the form and content of legislative acts, as on the readiness and willingness of the participants to engage willingly in an open trial.

However, it is still possible for procedural fairness to play a greater role in Chinese criminal justice system within the current political milieu of China. This would be possible not purely through introducing a more perfect external administrative and regulatory mechanism controlling the hosts of Chinese police, procurators, and judges. Rather, procedural fairness needs an internal moral foundation shared by the participants in a legal process which cannot be built through the mechanical reform of the governmental system. It might be built by means of reintroduction of the traditional Confucian values of humanity into the Chinese governmental machinery, but this introduction will unlikely be fruitful in a society driven primarily by material greed rather than by the love of virtue.

\section{References}

Ashworth, A. \& Redmayne, M. (2010) The Criminal Process. $4^{\text {th }}$ ed. Oxford: OUP. 
Balme, S. (2012) La justice pénale en Chine : son évolution et son avenir. Notes de l'IHEJ, Institut des hautes études sur la justice, $\mathrm{n}^{\circ} 1.6$. https://hal-sciencespo.archivesouvertes.fr/hal-01024544.

Bell, D. (2008) China's New Confucianism: Politics and Everyday life in a Changing Society Princeton: Princeton UP.

Blackstone's Criminal Practice . Oxford: OUP.

Blasek, K. (2105) Rule of Law in China: A Comparative Approach. Heidelberg: Springer.

Capowski, J. (2011) China's evidentiary and procedural reforms, the Federal Rules of Evidence, and the harmonization of civil and common law. 47 Tex. Int'l LJ, 455-504. http://www.tilj.org/content/journal/47/num3/Capowski455.pdf.

Chen, G. (2010). A Research on Several Theoretical and Practical Issues of Criminal Evidential System Reform [J]. China Legal Science, 6, 004.

Chen, J. (2008) Chinese Law: Context and Transformation. Leiden: Martinus Nijhoff.

Chen, J. (2013) Criminal Law and Criminal Procedure Law in the People's Republic of China: Commentary and Legislation. Leiden: Martinus Nijhoff.

Chen R. (2011). China's new exclusionary rule: An introduction. Columbia Journal of Asian Law 24(2), 229-246.

Chen, W. (2010). Retrospection and perspective: Chinese criminal procedure law (19792009). Frontiers of Law in China 5(4), 510-531.

Criminal Procedure Law of the PRC (CPL). 1979, 2012.

https://www.cecc.gov/resources/legal-provisions/criminal-procedure-law-of-the-peoplesrepublic-of-china

Damaska, M. (1973) Evidentiary barriers to conviction and two models of criminal procedure. 121 University of Pennsylvania Law Review 506.

Damaska, M. (1986) The Faces of Justice and State Authority: A Comparative Approach to the Legal Process. New Haven: Yale UP.

Daum, J. (2017) Exclusive focus: Why China's exclusionary rules won't stop police torture. https://www.chinalawtranslate.com/8481-2/?lang=en

David, R. \& Brierley, J. (1985) Major Legal Systems in the World Today: an Introduction to the Comparative Study of Law. $3^{\text {rd }}$ ed. London: Stevens \& Sons.

De Bary, (1998) Asian Values and Human Rights: A Confucian Communitarian Perspective. Boston: Harvard UP. 
Fang, Q. \& Li, X. (2017) Power versus Law in Modern China: Cities, Courts, and Communist Party. Lexington: University Press of Kentucky

Goldberg, E. (2007) Beyond Terror: Gender, Narrative, Human Rights. New Brunswick: Rutgers UP.

Glenn, H. (2014) Legal Traditions of the World: Sustainable Diversity in Law. $5^{\text {th }}$ ed. Oxford: OUP.

Guo, X. (2003) State and Society in China's Democratic Transition. New York: Routledge.

Guo, Z. (2017) Exclusion of illegally obtained confessions in China: an empirical perspective. 21 (2) International Journal of Evidence and Proof 30.

Hodgson, J. (2005) French Criminal Justice. Oxford: Hart.Jorg N., Field S. \& Brandt C. (1995) Are inquisitorial and adversarial systems converging? In: Harding, C., Fennel, P., \& Jorg, N. (Eds.) Criminal Justice in Europe: A Comparative Study. Oxford: Clarendon.

Keith, R. \& Lin, Z. (2001) Law and Justice in China's New Market Place. London: Palgrave Macmillan.

Lewis, M. K. (2010). Controlling abuse to maintain control: the exclusionary rule in China. NYUJ Int'l L. \& Pol., 43, 629-697

Lixin, G. (2009). Trend of Evolution of Chinese Mainland Prosecutorial System in the Context of Judicial Reform. In One Country, Two Systems, Three Legal Orders-Perspectives of Evolution . Springer: Berlin, Heidelberg. (pp. 319-328)

Lin, X. Gu, Z. \& Chen, C. (2017) Win some, lose some: reforms of China's simplified criminal procedure. 25(2) Asia Pacific Law Review 99-124.

Liu, S. \& Halliday, T. (2009) Recursivity in legal change: lawyers and reforms of China's criminal procedure law. 34(9) Law \& Social Inquiry 911-950.

Long Z. (2015). Approaches to and Methods of Substantiation of Court Hearing. Chinese Journal of Law, 5, 009.

Long Z. (2015b). The Reform toward "Proceedings Centered on Trial" and Its Limits. Peking University Law Journal, 4, 003.

Long Z. (2018). 检察机关内部机构及功能设置研究. Research on Internal Organization and Function Setting of Procuratorial Organs. The Jurist (法学家), 1, 141-151.

Lu, H. \& Miethe, T. (2007) China's Death Penalty: History, Law, and Contemporary Practices. New York: Routledge.

McConville, M. (2012) Criminal Justice in China: an Empirical Inquiry. Cheltenham: Edward Elgar. 
McConville, M. \& Pils, E. (Eds) (2013) Comparative Perspectives on Criminal Justice in China. Cheltenham: Edward Elgar.

McConville M. (2013) Comparative empirical co-ordinates and the dynamics of criminal justice in China and the West. In: McConville \& Pils (Eds.?, Comparative Perspectives on Criminal Justice in China. Cheltenham: Edward Elgar.

Mou, Y. (2017). Overseeing Criminal Justice: The Supervisory Role of the Public Prosecution Service in China. Journal of Law and Society, 44(4), 620-645.

Nessossi, E. (2013) Compromising for 'justice'? Criminal Proceedings and the ethical quandraries of Chinese lawyers. In: McConville \& Pils (Eds.), Comparative Perspectives on Criminal Justice in China. Cheltenham: Edward Elgar

Nesossi, E., Biddulph, S., Sapio, F.\& Trevaskes, S. (Eds.) (2016) Legal Reforms and Deprivation of Liberty in Contemporary China. New York: Routledge.

Peerenboom, R. (2002) China's Long March toward the Rule of Law. Cambridge: Cambridge UP.

Renton and Brown: Criminal Procedure according to the Law of Scotland. (2018) $6^{\text {th }}$ ed electronic version). Edinburgh: W Green/Sweet and Maxwell.

Roberts, P. (2008) Faces of justice adrift: Damaska's comparative method and the future of common law evidence. In: Jackson, J. \& Langer, M. (Eds.) Crime, Procedure and Evidence in a Comparative and International Context: Essays in Honour of Professor Mirjan Damaska. Oxford: Hart.

Simon, T., Feng, C. \& Nelson, L. (2016) China's Changing Legal System. London: Palgrave Macmillan.

Solzhenitsyn, A. (2003) The Gulag Archipelago, 1918-56: An Experiment in Literary Investigation. London: Random House.

Sun, C. (2018) Recht auf ein faires Verfahren und substanzielle Hauptverhandlung: Defizite und Fortschritte im chinesischen Recht, 5 Zeitschrift für Internationale Strafrechtsdogmatik 148-152. http://zis-online.com/dat/artikel/2018_5_1199.pdf

Sun, X. (2017) The Implementation of the International Covenant on Civil and Political Rights in China's Judicial System: Perspectives on Adoption of Exclusionary Rule in China. 5 Kathmandu Sch L Rev 162-168.

Supreme People's Court. (2012) Interpretation on the Application of the Criminal Procedure Law of the People's Republic of China. http://www.spp.gov.cn/sscx/201502/t20150217_91462.shtml

Supreme People's Court, the Supreme People's Procuratorate, and the Ministry of Public Security. (2017) Notice of the Supreme People's Court, the Supreme People's Procuratorate, 
the Ministry of Public Security and Other Departments on Issuing the Provisions on the Several Issues concerning the Strict Exclusion of the Illegally Collected Evidence in the Handling of Criminal Cases. http://www.spp.gov.cn/zdgz/201706/t20170627_194051.shtml

Swart, A. (1993) The Netherlands. In Van den Wyngaert, C. (Ed.) Criminal Procedure Systems in the European Community. London: Butterworths.

Trechsel, S. (2005) Human Rights in Criminal Proceedings. Oxford: OUP.

U.S. House of Representatives (2016) The Committee on the Judiciary (December $16^{\text {th }}$ ). https://judiciary.house.gov/wp-content/uploads/2013/07/Criminal2016.pdf

Wang, Z. \& Caruso, D. (2017) Is an oral-evidence based criminal trial possible in China? (2017). 21(2) International Journal of Evidence \& Proof 52.

Weigend, T. (2003) Is the criminal process about truth?: a German perspective. 26 Harvard Journal of Law and Public Policy 157.

Weigend, T. (2008) The decay of the inquisitorial ideal: plea-bargaining invades German criminal procedure. In: Jackson and Langer (Eds.) Crime, Procedure and Evidence in a Comparative and International Context: Essays in Honour of Professor Mirjan Damaska. Oxford: Hart.

Whitebread, C. \& Slobogin, C. (2003) Criminal Procedure. $4^{\text {th }}$ ed. New York: Foundation Press.

Xinhua (2013) China to abolish reeducation through labor system (November 15, 2013) http://en.people.cn/90785/8458027.html.

Yi, Z. (2017) Illegally obtained evidence defined. China Daily, $28^{\text {th }}$ June. http://www.chinadaily.com.cn/china/2017-06/28/content_29911578.htm

Yin, B. \& Duff, P. (2010) Criminal procedure in contemporary China. 59 International and Comparative Law Quarterly 1117.

Yu, M. (2017) The constructed truth: the making of police dossiers in China. 26(1) Social \& Legal Studies 69.

Zhang, J. (2014) The Tradition and Modern Transition of Chinese Law. Heidelberg: Springer.

Zhang, J. \& Yang, P. (2018) Rethinking Chinese evidence theories and reconstructing sytem of evidence: "a thread for the pearls of Chinese evidence". 13 Frontiers of Law in China 6.

Zhang Z. (2011) 应当重视检察机关内部机构改革 (Paying attention to the reform of the internal organs of the procuratorial organs) Procuratorate Daily (检察日报) August 19, p. 3 http://theory.people.com.cn/GB/15458913.html

Zou, K. (2006) China's Legal reform: Towards the Rule of Law. (Leiden: Martinus Nijhoff. 
Zuo, W. \& Ma, J. (2013) The role of criminal defence lawyers in China: an empirical study of D County, S Province. In McConville and Pils (eds) Comparative Perspectives on Criminal Justice in China. Cheltenham: Edward Elgar.

Zuo W. (2015) Unfinished Reform Empirical Study on Criminal Pre-trial Conference. Peking University Law Journal, 2, 009.

Zweigert, I. \& Kotz, H. (1998) An Introduction to Comparative Law. $3^{\text {rd }}$ ed. Oxford: OUP.

' Criminal Procedure Law of the PRC (CPL). 1979, 2012.

https://www.cecc.gov/resources/legal-provisions/criminal-procedure-law-of-the-peoplesrepublic-of-china

"Kostovski v Netherlands (1989) A 166, 12 EHRR 140.

ii See, for example, Article 227 of CPL. “Fair trial” 公正审判 is sometimes translated as 'impartiality of trial'.

"Rules on Certain Issues Relating to the Exclusion of Illegal Evidence in Criminal Cases. http://www.duihuahrjournal.org/2010/06/translation-chinas-new-rules-on.html.

v最高人民法院、最高人民检察院、公安部等印发《关于办理刑事案件严格排除非法证 据若干问题的规定》的通知 27.06.2017. Chinese text is available at:

http://www.spp.gov.cn/zdgz/201706/t20170627_194051.shtml and https://www.chinacourt.org/law/detail/2017/06/id/149505.shtml

${ }^{v i}$ Again note that the law assumes cooperation between the parties rather than conflict as in adversarial system.

vii最高人民法院关于适用《中华人民共和国刑事诉讼法》的解释（2012 年 11 月 5 日最 高人民法院审判委员会第 1559 次会议通过) (adopted by the 1559th meeting of the

Adjudication Committee of the Supreme People's Court on November 5, 2012) http://www.spp.gov.cn/sscx/201502/t20150217_91462.shtml

vii Chinese text: 勍能浊以静之徐清。孰能安以动之徐生. Daodejing, 15.

${ }^{\text {ix }}$ Chinese text is available at: 中共中央关于全面推进依法治国若干重大问题的决定. (二 ○一四年十月二十三日中国共产党第十八届中央委员会第四次全体会议通过）

$10^{\text {th }}$ of October, 2014. http://cpc.people.com.cn/n/2014/1029/c64387-25927606.html 